ISSN: 2302-8556

\title{
Pengaruh Ukuran Perusahaan, Profitabilitas, Financial Leverage, dan Winner/Loser Stock pada Perataan Laba Perusahaan Manufaktur
}

\author{
Putu Intan Adriani ${ }^{1}$ \\ I G. A. M. Asri Dwija Putri ${ }^{2}$ \\ Gede Agus Indra Tenaya K. ${ }^{3}$
}

${ }^{1}$ Fakultas Ekonomi dan Bisnis Universitas Udayana (Unud), Bali, Indonesia
e-mail: intanadriani05@ gmail.com/ Telp: +62 85792130500
${ }^{2}$ Fakultas Ekonomi dan Bisnis Universitas Udayana (Unud), Bali, Indonesia
${ }^{3}$ Fakultas Ekonomi dan Bisnis Universitas Udayana (Unud), Bali, Indonesia

\begin{abstract}
ABSTRAK
Penelitian ini dilakukan pada perusahaan manufaktur yang tercatat di Bursa Efek Indonesia (BEI) selama periode 2013-2016. Jumlah sampel yang digunakan sebanyak 37 perusahaan yang dipilih melalui metode purposive sampling dengan 4 tahun masa pengamatan sehingga total sampel yang digunakan menjadi 148 sampel. Indeks Eckel dipakai sebagai indikator pembeda antara perusahaan yang melaksanakan perataan laba dan tidak melaksanakan perataan laba. Pengumpulan data dilakukan dengan metode observasi non partisipan. Teknik analisis data yang digunakan adalah regresi logistik. Berdasarkan hasil analisis pada penelitian ini menunjukkan bahwa variabel profitabilitas berpengaruh pada perataan laba, sedangkan variabel ukuran perusahaan, financial leverage, dan winner/loser stock tidak mempunyai pengaruh pada perataan laba.

Kata kunci: Ukuran perusahaan, profitabilitas, financial leverage, winner/loser stock, perataan laba.
\end{abstract}

\begin{abstract}
This research was conducted at a manufacturing company listed on Indonesia Stock Exchange (BEI) during the period 2013-2016. The number of samples used are 37 companies selected through purposive sampling method with 4 years of observation so that the total sample used to be 148 samples.. The Eckel Index is used as a distinguishing indicator between firms that do income smoothing and do not make income smoothing. Data collection was done by non participant observation method. Data analysis technique used is logistic regression. Based on the results of analysis in this study indicate that profitability variables affect the income smoothing, while the variable size of the company, financial leverage, and winner/loser stock has no effect on income smoothing. Keywords: Firm size, profitability, financial leverage, winner/loser stock, income smoothing.
\end{abstract}

\section{PENDAHULUAN}

Informasi yang terdapat di dalam laba memiliki tujuan untuk mengetahui cara kinerja dari manajemenapakah kinerjanya baik atau tidak, membantu dalam memperkirakan hasil laba di masa depan, serta memperkirakan kompetensi 
Putu Intan Andriani, I G.A.M. Asri Dwija Putri dan Gede Agus Indra Tenaya K. Pengaruh...

perusahaan meminjam dana pada kreditor (Kirschenheiter dan Melumad 2002). Investor acap kali tertarik tentang keuntungan perusahaan, sehingga manajemen berpeluang untuk melaksanakan rencana yang akan menaikkan laba perusahaan (Beattie et al, 1994).

Schroeder (2009) mendeskripsikan perataan laba dikerjakan manajer karena terjadi naik-turunnya atau fluktuasi laba di dalam perusahaan dan tindakan manajer disangka normal bagi perusahaan. Manajemen berminat melaksanakan perataan laba disebabkan lantaran manajemen menyenangi perusahaan yang mempunyai laba rata seperti halnya investor, karena menurut investor laba yang rata diduga perusahaan itu baik (Atik, 2008). Perataan laba merupakan fenomena yang umum terjadi sebagai usaha manajemen untuk mengurangi fluktuasi laba yang dilaporkan.

Juniarti dan Corolina (2005) mengatakan tindakan manajemen untuk melaksanakan perataan laba adalah untukserta mengurangi fluktuasi pada pelaporan labaserta memberikan anggapan baik kepada pemilik perusahaan dan kreditur terhadap kinerja manajemen perusahaan. Prasetya dan Rahardjo (2013) menyatakan bahwa perataan laba ini umumnya dilakukan untuk menjaga hubungan antara manajer dan pekerja untuk mengurangi gejolak kenaikan laba dalam pelaporan laba yang cukup tajam dan mengurangi pajak.

Perusahaan yang melaksanakan praktik perataan laba terjadi pada PT Kimia Farma. PT Kimia Farma disangka melakukan mark up laba bersih pada laporan keuangan tahun 2001. Laporan tersebut menyatakan, PT Kimia Farma berhasil mendapatkan laba sebanyak Rp 132 miliar. Tetapi, laba yang dilaporkan tersebut kenyataannya hanya sebesar Rp 99 miliar (Irawan, 2013). 
Kasus perataan laba lainnya terjadi pada PT Indofarma pada tahun 2004, OJK menemukan bahwa terdapat nilai barang dalam proses pada tahun 2001 lebih tinggi dari nilai seharusnya yaitu sebesar Rp 28,87 miliar. Hal ini mengakibatkan harga pokok penjualan mengalami understated dan laba bersih juga mengalami overstated dengan nilai yang sama (http://m.detik.com).

Tahun 2015, PT Toshiba Corporation merupakan perusahaan asal Jepang yang memproduksi dan memasarkan berbagai peralatan listrik dan produk elektornik canggih terbukti melakukan pembohongan publik dengan cara menggelembungkan keuntungan perusahaan di laporan keuangan. Panel investigasi independen yang terdiri dari akuntan independen dan pengacara menemukan bahwa laba operasional Toshiba telah dibesar-besarkan sebesar 1,22 miliar US (www.beritasatu.com).

Beberapa faktor-faktor yang memengaruhi praktik perataan laba antara lain; ukuran perusahaan merupakan suatu ukuran yang dapat mengklasifikasikan besar kecilnya perusahaan dengn beragam cara, antara lain total aktiva, log size, nilai pasar saham, dan lain-lain. Ukuran perusahaan menjadi salah satu bahan pertimbangan investor dalam menentukan keputusan untuk memasukkan dananya sebagai bentuk investasi pada suatu perusahaan. Pada umumnya perusahaan besar lebih diminati oleh para penanam modal dibandingkan dengan perusahaan kecil karena penanam modalberpendapat jika perusahaan besarakan menghasilkan laba yang lebih tinggi (Junianto, 2013). Arfan dan Wahyuni (2010) yang mengungkapkan ukuran perusahaan mempunyai pengaruh positif pada perataan laba, namun ada hasil berbeda yang diperoleh dari penelitian yang dilakukan oleh 
Putu Intan Andriani, I G.A.M. Asri Dwija Putri dan Gede Agus Indra Tenaya K. Pengaruh...

Suryani (2015) yang menyatakan bahwa ukuran perusahaan tidak memengaruhi perataan laba.

Profitabilitas merupakan rasio yang digunakan untuk mengukur kinerja manajemen dalam menghasilkan laba atas aktiva dan penjualan. Profitabilitas berpengaruh terhadap praktik perataan laba karena jika manajemen menghasilkan laba lebih rendah atau lebih tinggi dari tingkat laba yang telah dianggap wajar oleh manajemen, maka manajemen akan membuat perataan laba agar laba berada pada tingkat laba yang dianggap normal oleh manajemen. Pratiwi (2017) menyatakan profitabilitas mempunyai pengaruh positif pada perataan laba, sedangkanSuryani (2015) menyatakan profitabilitas tidak mempunyai pengaruh pada praktik perataan laba.

Financial leverage memperlihatkanseberapa jauh aset perusahaan dibiayai oleh hutang (Kasmir, 2014). Financial leverage merujuk pada penggunaan hutang untuk pembiayaan perusahaan. Semakin besar hutang, maka semakin besar risiko yang dimiliki investor, yang mengakibatkan perusahaan harus memperbesar keuntungan bagi investor dan ini yang membuat perusahaan cenderung melaksanakan perataan laba. Penelitian yang dilakukan Prasetya dan Rahardjo (2013) dan Astuti dan Widyarti (2013) menyatakan bahwa financial leverage berpengaruh positif signifikanpada praktik perataan laba, sedangkan penelitian Handayani dan Fuad (2015) menyatakan leverage berpengaruh negatif pada perataan laba.

Winner/loser stockmerupakan pengelompokkan perusahaan berdasarkan return saham dari tiap perusahaan.Saham yang mempunyaireturn lebih besar 
daripada return rata-rata pasar atau saham yang memberikan return positif disebut winner stock, sedangkan loser stock adalah saham yang mempunyaireturn sama dengan atau lebih kecil daripada return rata-rata pasar dapat dikatakan juga sebagai saham yang memberikan returnnegatif (Sunarto, 2006). Arfan dan Wahyuni (2010) menyatakan winner/loser stock mempunyai pengaruh positif pada perataan laba. Penelitian Supriastuti dan Warnanti (2015) mengungkapkanwinner/loser stock mempunyai pengaruh secara signifikan pada perataan laba, sedangkan penelitian Iskandar dan Suardana (2016), mengungkapkanwinner/loser stock tidak mempunyai pengaruh pada perataan laba.

Berdasarkan uraian di atas, maka rumusan masalah pada penelitian ini adalah: 1) Apakah ukuran perusahaan berpengaruh pada perataan laba perusahaan manufaktur yang terdaftar di BEI?; 2) Apakah profitabilitas berpengaruh pada perataan laba perusahaan manufaktur yang terdaftar di BEI?; 3) Apakah financial leverage berpengaruh pada perataan laba perusahaan manufaktur yang terdaftar di BEI?; 4) Apakah winner/loser stock berpengaruh pada perataan laba perusahaan manufaktur yang terdaftar di BEI?.

Mengacu pada rumusan masalah tersebut, maka tujuan dalam penelitian ini meliputi 1) untuk mengetahui pengaruh ukuran perusahaan pada perataan laba perusahaan manufaktur yang terdaftar di BEI; 2) untuk mengetahui pengaruh profitabilitaspada perataan laba perusahaan manufaktur yang terdaftar di BEI; 3) untuk mengetahui pengaruh financial leverage pada perataan laba perusahaan manufaktur yang terdaftar di BEI; 4) untuk mengetahui pengaruh winner/loser stock pada perataan laba perusahaan manufaktur yang terdaftar di BEI. 
Putu Intan Andriani, I G.A.M. Asri Dwija Putri dan Gede Agus Indra Tenaya K. Pengaruh...

Penelitian ini diharapkan dapat memberikan kegunaan secara teoritis maupun secara praktis. Secara teoritis, penelitian ini mengonfirmasi teori agensi dan teori akuntansi positif yang diharapkan dapat digunakan sebagai tambahan ilmu pengetahuan, informasi serta wawasan bagi akademisi. Diharapkan dapat menjadi refensensi bagi penelitian selanjutnya yang berkaitan dengan praktik perataan laba.

Secara praktis, penelitian ini diharapkan dapat memberikan manfaat bagi perusahaan yakni bisa memberikan penjelasan mengenai perataan laba untukhubungannya dengan pelaporan keuangan perusahaan. Bagi investor penelitian ini diharapkan dapat memberikan informasi mengenai praktik perataan laba, sehingga investor bisa melaksanakan analisa secara cermat dan menentukan keputusan yang tepat berhubungan dengan keputusan investasi.

Teori agensi adalah teori yang membahas mengenai suatu bentuk kesepakatan atau kontrak antara manajemen (agent) dan pemilik modal (principal) dalam mengelola suatu perusahaan. Teori agensi mengemukakan bahwa konflik kepentingan antara manajer dan pemilik mempengaruhi terjadinya praktik manajemen laba, ini disebabkan karena ketika semua pihak berusaha untuk mencapai atau mempertahankan tingkat kemakmuran yang dikehendakinya atau dapat juga untuk mempertahankan posisinya di perusahaan.

Jensen dan Meckling (1976) menyatakan bahwa hubungan keagenan terjadi ketika pemilik modal (principal) mempekerjakan orang lain manajemen (agent) untuk melakukan beberapa pekerjaan bagi mereka. Principal memberikan wewenang kepada agent untuk melakukan semua kegiatan atas nama principal termasuk dalam mengambil keputusan. Agent sebagai pihak pengelola perusahaan 
mempunyai lebih banyak informasi mengenai keadaan perusahaan dibandingkan dengan principal. Kondisi ini disebut dengan asimetri informasi. Kondisi asimetri informasi ini dapat memberikan peluang bagi agent untuk melakukan perataan laba.

Pihak agent dan principal memiliki kepentingan yang berbeda. Agent pada umumnya bertindak berdasarkan kepentingan yang dimilikinya, sedangkan principal mengharapkan agent untuk dapat melaksanakan beberapa pekerjaan tertentu yang terkait dengan kepentingan principal misalnya, principallebih menginginkan pengembalian sebesar-besarnya dari investasi yang dilakukannya pada perusahaan, sedangkan agent lebih menginginkan mendapatkan kompensasi atau bonus yang semaksimal mungkin atas pekerjaan yang dilakukannya.

Praktik perataan laba memiliki kaitan dengan teori akuntansi positif. Teori ini merupakan teori yang memperkirakan tindakan bagaimana manajer memilih kebijakan akuntansi sertacara manajer akan merespons kebijakan akuntansi baru yang diusulkan (Scott, 2006). Watt dan Zimmerman (1978) menyatakan tujuan teori akuntansi ialah untuk menjelaskan dan memprediksi praktek akuntansi. Terdapat tiga hipotesis dalam teori akuntansi positif mengenai motivasi manajemen melaksanakan manajemen laba, antara lain: hipotesis rencana bonus (bonus plan hypothesis), hipotesis perjanjian hutang (debt covenant hypothesis), dan hipotesis biaya politik (political cost hypothesis).

Ukuran perusahaan merupakan suatu skala yang mampu mengklasifikasikan ukuran perusahaan dengan bermacam cara, yakni total aktiva, log size, nilai pasar saham, dan lain-lain. Ukuran perusahaan dinilai dengan logaritma natural dari total aset suatu perusahaan. Tucker dan Zarowin (2006) menyatakan bahwa 
Putu Intan Andriani, I G.A.M. Asri Dwija Putri dan Gede Agus Indra Tenaya K. Pengaruh...

semakinbesar skala perusahaan mempunyai lebih besar dorongan untuk melaksanakan perataan laba dibandingkan dengan perusahaan yang skalanya lebih kecil, dikarenakan perusahaan besar dapat menjadi subjek pengawasan yang lebih ketat dari pemerintah dan masyarakat. Penelitian yang dilakukan oleh Iskandar dan Suardana (2016) menyatakan ukuran perusahaan memiliki pengaruh pada praktik perataan laba. Menurut Pratiwi (2017) ukuran perusahaan mempunyai pengaruh positif pada perataan laba, sedangkan penelitian Suryani (2015) menyimpulkan ukuran perusahaan tidak signifikanpada perataan laba. Perusahaan besar diprediksi akan menghindari naik-turunnya laba yang tajam, yang disebabkan oleh penambahan laba yang ekstrim akan mengakibatkan kenaikan pajak, sedangkanpengurangan laba yang tajam memberikan anggapan yang kurang baik. Oleh sebab itu perusahaan yang berukuran besar condong melakukan fluktuasi keuntungan. Sesuai dengan penjelasan sebelumnya dirumuskan hipotesis yaitu:

$\mathrm{H}_{1}$ : Ukuran perusahaan berpengaruh positif pada perataan laba perusahaan manufaktur yang terdaftar di BEI.

Profitabilitas adalah kompetensi suatu perusahaan dalam memeroleh keuntungan pada suatu periode tertentu. Profitabilitas diproksikan dengan rasio Net profit margin. Net profit margin menggambarkan kemampuan perusahaan dalam menghasilkan keuntungan pada suatu tingkat penjualan. Semakin tinggi rasio net profit margin memperlihatkan semakin tinggi kemampuan suatu perusahaan mendapatkan laba. Manajer dalam meyakinkan investor cenderung memberikan informasi yang terperinci mengenai profitabilitas perusahaan (Serimbing, 2013).

Investor saaat menentukan keputusan terkait investasi yang dilakukan akan cenderung memperhatikan laba setelah pajak. Fenomena ini mendorong 
manajemen melakukan perataan laba, supaya laba kelihatan stabil (Widana dan Yasa, 2013).

Budiasih (2009), Widana dan Yasa (2013) dan Pratiwi (2017) menyatakan profitabilitas berpengaruh positif terhadap perataan laba, sedangkan menurut Suryani (2015) menyimpulkan bahwa profitabilitas tidak berpengaruh terhadap praktik perataan laba. Sesuai dengan penjelasan sebelumnya dirumuskan hipotesis yaitu:

$\mathrm{H}_{2}$ : Profitabilitas berpengaruh positif pada perataan laba perusahaan manufaktur yang terdaftar di BEI.

Financial leverage menerangkan seberapa jauh aset perusahaan dibiayai oleh hutang. Perusahaan yang memiliki rasio leverage yang tinggidiartikan bahwa perusahaan mempunyai hutang yang besar kepada pihak kreditor. Mempunyai hutang yang besar menyebabkan risiko yang dialami perusahaan menjadi bertambah. Astuti dan Widyarti (2013) mengungkapkan terdapat gejala perusahaan melaksanakan perataan laba untuk menghindari pelanggaran perjanjian hutang bisa dipandang dari kemampuan perusahaan untuk melunasi hutangnya dengan memanfatkan aktiva perusahaan. Perusahaan dengan tingkat leverage tinggi disangka akan melaksanakan perataan laba dikarenakan perusahaan tersebut kemungkinan mengalami default, oleh karena itu manajemen mengambil kebijakan agar bisa meningkatkan pendapatan. Nilai leverage yang tinggi menggambarkan perusahaan yang tidak sehat.

Riset yang dilakukan oleh Prasetya dan Rahardjo (2013) financial leverage berpengaruh positif signifikan terhadap praktik perataan laba. dan Alexandri dan Anjani (2014) menyatakan financial leverage mempunyai pengaruh signifikan 
Putu Intan Andriani, I G.A.M. Asri Dwija Putri dan Gede Agus Indra Tenaya K. Pengaruh...

pada pemerataan laba, berbeda dengan Handayani dan Fuad (2015) yang mengungkapkan leverage mempunyai pengaruh negatif pada perataan laba. Budiasih (2009) mengungkapkan jika hutang perusahaan semakin bertambah, maka risiko yang ditanggung perusahaan akan semakin besar, sehingga penanam modal akan meminta tingkat keuntungan yang semakin tinggi. Sesuai dengan penjelasan sebelumnya dirumuskan hipotesis yaitu:

$\mathrm{H}_{3}$ : Financial leverage berpengaruh positif pada perataan laba perusahaan manufaktur yang terdaftar di BEI.

Winner stock ialah golongan perusahaan yang memilikipengembaliansaham yang positif, berbanding terbalik dengan loser stock adalah golongan perusahaan yang memiliki pengembaliansaham negatif (Supriastuti dan Warnanti, 2015). Manajemen perusahaan winner stock berpeluang melaksanakan perataan laba untuk memeroleh dan menjaga kedudukannya di golongan winner stock, lain halnya dengan perusahaan loser stock yang mempunyai tujuan menaikkan nilai perusahaan sehingga perusahaan loser stock dapat mencapai kedudukan winner stock dengan melaksanakan perataan laba (Salno dan Baridwan, 2000).

Winner/loser stock mempunyai pengaruh positif pada perataan laba (Arfan dan Wahyuni, 2010). Penelitian Supriastuti dan Warnanti (2015) mengemukakan winner/loser stock mempunyai pengaruh signifikan pada perataan laba, sedangkan penelitian Iskandar dan Suardana (2016), mengungkapkan winner/loser stock tidak memiliki pengaruh pada praktik pemerataan laba.

Pergantian harga saham yang konstan dipengaruhi oleh laba yang konstan pula. Laba yang stabil menyampaikan kesan kepada penanam modal bahwa tingkat return saham yang diinginkan tinggi serta risiko portofolio saham yang rendah, 
maka kemampuan perusahaan akan terlihat bagus. Saat perusahaan dalam kondisi kedudukan winner stock perusahaan akan konsisten melindungi kedudukannya di winner stock serta menjauhi statusloser stock dengan melakukan perataan laba (Arfan dan Wahyuni, 2010). Sesuai dengan penjelasan sebelumnya dirumuskan hipotesis yaitu:

$\mathrm{H}_{4}$ : Winner/loser stock berpengaruh positif pada perataan laba perusahaan manufaktur yang terdaftar di BEI.

\section{METODE PENELITIAN}

Pada riset ini digunakan pendekatan kuantitatif yang berbentuk asosiatif sebagai desain penelitian dimana penelitian ini bertujuan untuk dapat melihat bagaimana kaitan antar variabel (Sugiyono, 2014). Penelitian ini dilaksanakan pada perusahaan manufaktur yang tercatat di BEI. Objek penelitian ini ialah laporan keuangan dari perusahaan manufaktur yang dipublikasi oleh BEI untuk tahun 2013-2016. Variabel independen penelitian ini adalah ukuran perusahaan, profitabilitas, financial leverage dan winner/loser stock, serta variabel dependennya adalah perataan laba.

Ukuran perusahaan diukur dengan logaritma natural dari total aset (Budiasih, 2009). Rumus dari logaritma natural:

Ukuran perusahaan $=L n$ Total Aktiva

Profitabilitas ialah kompetensi suatu perusahaan dalam memeroleh keuntungan pada suatu periode tertentu. Profitabilitas diukur dengan menggunakan rasio net profit margin.

Profitabilitas $=\frac{\text { Laba bersih setelah pajak }}{\text { Total penjualan }}$ 
Putu Intan Andriani, I G.A.M. Asri Dwija Putri dan Gede Agus Indra Tenaya K. Pengaruh...

Financial leverage menerangkanseberapa jauh aset perusahaan dibiayai oleh hutang (Kasmir, 2014). Perusahaan dengan tingkat leverage tinggi diduga akan melakukan perataan laba dikarenakan perusahaan tersebut kemungkinan mengalami default, oleh karena itu manajemen mengambil kebijakan agar bisa meningkatkan pendapatan. Financial leverage diukur dengan debt to total assets (DAR).

DAR $=\frac{\text { Total hutang }}{\text { Total aset }}$

Winner stock ialah golongan perusahaan yang memiliki pengembalian saham positif, sedangkan loser stock adalah golongan perusahaan yang memiliki pengembalian saham negatif. Kedudukan winner/loser stock ditentukan dengan menghitung return saham dari tiap perusahaan lalu membandingkannya dengan return pasar. Return pasar yaitu Indeks Harga Saham Gabungan (IHSG) BEI.

$\mathrm{R}_{\mathrm{t}}=\frac{P t-P t-1}{P t-1}$

Keterangan:

$\mathrm{R}_{\mathrm{t}}=$ Return saham pada tahun $\mathrm{t}$

$\mathrm{P}_{\mathrm{t}}=$ Rata-rata harga saham penutupan bulanan pada tahun $\mathrm{t}$

$\mathrm{P}_{\mathrm{t}-1}=$ Rata-rata harga saham penutupan bulanan pada tahun $\mathrm{t}-1$

$\mathrm{R}_{\mathrm{mt}}=\frac{I H S G t-I H S G t-1}{I H S G t-1}$

Keterangan:

$\mathrm{R}_{\mathrm{mt}} \quad=$ Return pasar pada tahun $\mathrm{t}$

$\mathrm{IHSG}_{\mathrm{t}}=\mathrm{IHSG}$ pada tahun $\mathrm{t}$

$\mathrm{IHSG}_{\mathrm{t}-1}=\mathrm{IHSG}$ pada tahun $\mathrm{t}-1$

Apabila:

$\mathrm{Rt}>\mathrm{Rmt}$, maka perusahaan berkedudukan sebagai winner stock (diberi nilai 1)

$\mathrm{Rt}<\mathrm{Rmt}$, maka perusahaan berkedudukan sebagai loser stock (diberi nilai 0)

Perataan laba ialah cara manajemen dalam meminimalkan naik-turunnya laba yang dihasilkan perusahaan, maka dari itu laba yang diperoleh suatu 
perusahaan dari satu periode ke periode selanjutnya akan terlihat rata (smooth) dan stabil. Indeks Eckel (1981) dipakai untuk mengukur perataan laba. Hasil dari Indeks Eckel berbentuk variabel dummy yang membedakan antara perusahaan-perusahaan yang melakukan perataan laba. Adapun rumus Indeks Eckel yaitu:

Indeks Eckel $=\frac{\mathrm{CV} \Delta I}{\mathrm{CV} \Delta \mathrm{S}}$

Keterangan:

$\mathrm{CV} \Delta \mathrm{I}$ : Koefisien variasi untuk perubahan laba

$\mathrm{CV} \Delta \mathrm{S}$ : Koefisien variasi untuk perubahan penjualan

$\mathrm{CV} \Delta \mathrm{I}$ dan $\mathrm{CV} \Delta \mathrm{S}$ dapat dihitung sebagai berikut:

$\sqrt{\frac{(\Delta x-\Delta X)^{2}}{n-1}}: \Delta \mathrm{X}$

Keterangan:

$\Delta \mathrm{x} \quad$ : Perubahan penghasilan bersih/laba (I) atau penjualan (S) antara tahun $\mathrm{n}$ dengan n-1

$\Delta \mathrm{X} \quad$ : Rata-rata perubahan penghasilan bersih/laba (I) atau penjualan (S) antara tahun $\mathrm{n}$ dengan $\mathrm{n}-1$

n : Tahun yang diteliti

Apabila nilai indeks perataan laba lebih besar atau sama dengan 1 berarti perusahaan dikelompokkan menjadi perusahaan yang tidak melakukan perataan laba, sedangkan jika nilai indeks perataan laba kurang dari 1, sehingga perusahaan dikelompokkan menjadi perusahaan yang melaksanakan perataan laba.

Populasi pada penelitian ini ialah semua perusahaan manufaktur yang tercatat di BEI periode 2013-2016 sebanyak 144 perusahaan. Sampel yang dipakai pada penelitian ini ditentukan dengan metode purposive sampling dengan kriteria berikut 1) perusahaan manufaktur yang terdaftar di BEI pada periode 2013-2016, 2) perusahaan manufaktur yangmenerbitkan laporan keuangannya secara lengkap selama periode 2013-2016 secara berkesinambungan, 3) perusahaan yang tidak 
Putu Intan Andriani, I G.A.M. Asri Dwija Putri dan Gede Agus Indra Tenaya K. Pengaruh...

mengalami kerugian selama 2013-2016, 4) perusahaan tersebut memakai rupiah untuk mata uang pelaporan, 5) perusahaan manufaktur yang mempunyai kelengkapan informasi berhubungan dengan parameter-parameter perhitungan yang dijadikan variabel dalam penelitian ini. Berdasarkan kriteria-kriteria tersebut didapat sampel sebanyak 37 perusahaan dengan 4 tahun pengamatan sehingga total sampel menjadi 148 seperti yang disajikan dalam Tabel 1.

\section{Tabel 1.}

\section{Tahap Pemilihan Sampel}

\begin{tabular}{|c|c|c|}
\hline No. & Kriteria & Jumlah \\
\hline 1 & $\begin{array}{l}\text { Perusahaan manufaktur yang tercatat di BEI periode 2013- } \\
2016 .\end{array}$ & 144 \\
\hline 2 & $\begin{array}{l}\text { Perusahaan manufaktur yang menerbitkan laporan } \\
\text { keuangannya secara tidak lengkap selama periode 2013- } \\
2016 \text {. }\end{array}$ & (52) \\
\hline 3 & $\begin{array}{l}\text { Perusahaan yang mendapat kerugian selama periode } 2013 \text { - } \\
2016 .\end{array}$ & (38) \\
\hline 4 & $\begin{array}{l}\text { Perusahaan yang tidak memakai rupiah sebagai mata uang } \\
\text { pelaporan. }\end{array}$ & (10) \\
\hline 5 & $\begin{array}{l}\text { Perusahaan manufaktur yang tidak mempunyai } \\
\text { kelengkapan informasi berhubungan dengan parameter- } \\
\text { parameter perhitungan yang dijadikan variabel dalam } \\
\text { penelitian ini }\end{array}$ & (7) \\
\hline $\begin{array}{l}\text { Jum } \\
\text { Jum }\end{array}$ & $\begin{array}{l}\text { th perusahaan sampel yang terpilih } \\
\text { h amatan selama } 3 \text { tahun penelitian }\end{array}$ & $\begin{array}{c}37 \\
148\end{array}$ \\
\hline
\end{tabular}

Metode pengumpulan data dalam penelitian ini adalah metode observasi non partisipan, yaitu peneliti hanya menjadi pengamat bebas yang tidak terlibat secara langsung dalam proses kegiatan pengamatan. Teknik analisis data pada penelitian ini adalah analisis regresi logistik dirumuskan sebagai berikut:

$$
\operatorname{Ln} \frac{(p)}{(1-p)}=\alpha+\beta_{1} \mathrm{UP}+\beta_{2} \mathrm{NPM}+\beta_{3} \mathrm{DAR}+\beta_{4} \mathrm{WLS}+\mathrm{e}
$$

Keterangan:

$\begin{array}{ll}\text { Y } & : \text { Kualitas laba } \\ \alpha & : \text { Konstanta } \\ \beta 1, \beta_{2}, \beta_{3}, \beta_{4} & : \text { Koefisien regresi variabel } \\ \mathrm{UP} & : \text { Ukuran perusahaan } \\ \mathrm{NPM} & : \text { Profitabilitas }\end{array}$




$\begin{array}{ll}\text { DAR } & \text { : Financial leverage } \\ \text { WLS } & : \text { Winner/loser stock } \\ \mathrm{e} & : \text { Kesalahan (standar } \text { error) }\end{array}$

\section{HASIL DAN PEMBAHASAN}

Statistik deskriptif dipakai untuk mendeskripsikan variabel-variabel penelitian dalam ini. Hasil uji statistik deskriptif dalam penelitian ini bisa dilihat pada Tabel 2.

Tabel 2.

Hasil Statistik Deskriptif Variabel Penelitian

\begin{tabular}{lrrrrr}
\hline & N & Minimum & Maximum & \multicolumn{1}{c}{ Mean } & Std. Deviation \\
\hline Ukuran Perusahaan & 148 & 13,000 & 31,200 & 23,57926 & 5,101744 \\
Profitabilitas & 148 & 0,001 & 0,509 & 0,09272 & 0,076135 \\
Financial Leverage & 148 & 0,074 & 0,881 & 0,36577 & 0,173172 \\
Winner/Loser Stock & 148 & 0 & 1 & 0,49 & 0,502 \\
Status Perataan Laba & 148 & 0 & 1 & 0,60 & 0,491 \\
Valid N (listwise) & 148 & & & & \\
Sumber: Data diolah, 2018 & & & &
\end{tabular}

Berdasarkan Tabel 2 dapat dijelaskan bahwa variabel perataan laba memiliki mean sebesar 0,60 dengan nilai minimum sebesar 0 dan nilai maksimum sebesar 1 . Mean sebesar 0,60 berada di antara nilai minimum dan maksimum memperlihatkan bahwa sampel perusahaan mempunyai tingkat perataan laba tidak terlalu tinggi dan tidak terlalu rendah. Standar deviasi sebesar 0,491kurang dari dari nilai mean memberikan makna penyebaran data tidak jauh berbeda.

Nilai minimum variabel ukuran perusahaan sebesar 13,000, maksimum 31,200 dan mean sebesar 23,57926. Standar deviasi 5,101744 kurang dari dari nilai mean berarti penyebaran data tidak jauh berbeda. Nilai minimum variabel profitabilitas sebesar 0,001, maksimum 0,509 dan mean sebesar 0,09272. Nilai standar deviasi 0,076135 kurang dari nilai mean berarti penyebaran data tidak jauh berbeda. 
Putu Intan Andriani, I G.A.M. Asri Dwija Putri dan Gede Agus Indra Tenaya K. Pengaruh...

Nilai minimum variabel financial leveragesebesar 0,074 dan maksimum 0,881 dan mean sebesar 0,36577. Standar deviasi 0,173172 kurang dari nilai mean berarti penyebaran data tidak jauh berbeda. Nilai minimum variabel winner/loser stock sebesar0 dan maksimum 1 dan mean sebesar 0,49. Perusahaan yang berada pada posisi winner stock sebanyak 72 perusahaan dan 76 perusahaan berada pada posisi loser stock dengan total obsevasi sebanyak 148 perusahaan.

Variabel terikat dalam penelitian ini adalah variabel kategorial, yakni dengan kategori melaksanakan perataan laba dan tidak melaksanakan perataan laba, maka digunakan analisis regresi logistik. Analisis regresi logistik yang pertama merupakanpenilaian kelayakan model regresi. Hasil dari penilaian kelayakan model regresi dapat dilihat pada Tabel 3.

Tabel 3.

\begin{tabular}{lcccc}
\multicolumn{4}{c}{ Hasil Uji Hosmer dan Lemeshow } \\
\hline Step & Chi-square & df & Sig. \\
\hline 1 & 1,997 & 8 & 0,981 \\
\hline Sumber: & data diolah, 2018 & & &
\end{tabular}

Sesuai dengan Tabel 3, diketahui nilai uji Hosmer dan Lemeshow adalah 1,997 dengan signifikansi sebesar $0,981>0,05$, sehingga $\mathrm{H}_{0}$ diterima, artinya model regresi layak digunakan untuk analisis selanjutnya, karena tidak ada perbedaan yang signifikan antara model dengan data pengamatannya.

Analisis regresi logistik yang kedua adalah menilai keseluruhan model. Hasil dari menilai keseluruhan model ditampilkan pada Tabel 4 dan Tabel 5.

Tabel 4.

\begin{tabular}{cccc}
\multicolumn{3}{c}{ Iteration History $($ Block Number $=\mathbf{0})$} \\
\hline Iteration & $\begin{array}{c}\mathbf{- 2} \text { Log } \\
\text { likelihood }\end{array}$ & $\begin{array}{c}\text { Coefficients } \\
\text { Constant }\end{array}$ \\
\hline \multirow{3}{*}{ Step 0} & 1 & 199,049 & 0,405 \\
& 2 & 199,048 & 0,411 \\
& 3 & 199,048 & 0,411 \\
\hline Sumber: & data
\end{tabular}

Sumber: data diolah, 2018 
Tabel 5.

Iteration History $($ Block Number $=1)$

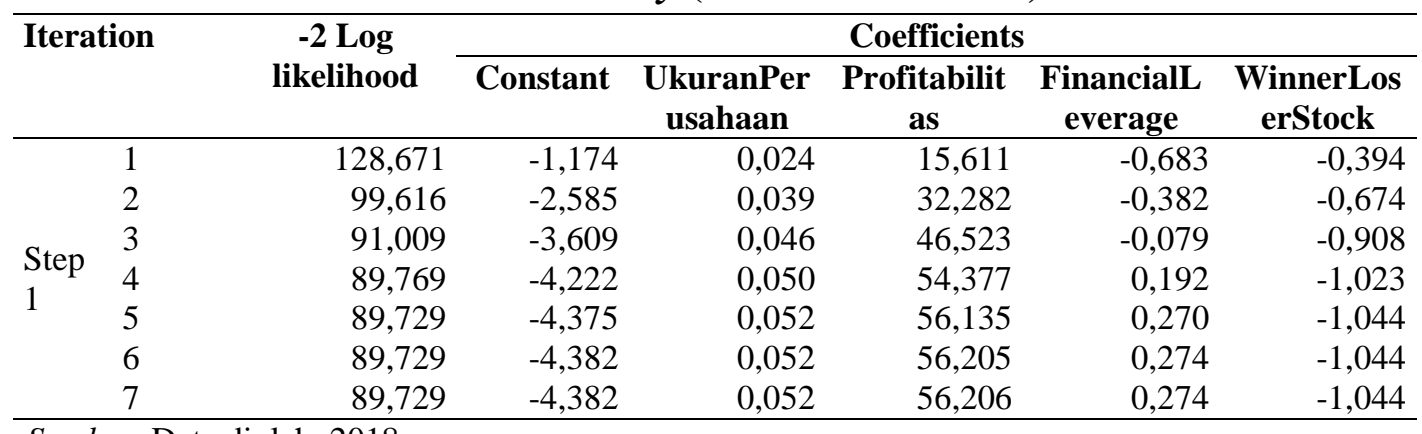

Sumber: Data diolah, 2018

Berdasarkan hasil yang diperlihatkan Tabel 4 dapat diketahui bahwa menilai keseluruhan model dilaksanakan dengan membandingkan nilai antara -2 Log Likehood (-2LL) pada awal (Block Number $=0$ ), dimana model hanya menginput konstanta dengan nilai -2 Log Likelihood (-2LL) pada akhir (Block Number $=1)$, dimana model menginput konstanta dan variabel bebas. Nilai -2LL awal ialah sebesar 199,049, sesudah diinput empat variabel bebas, maka nilai -2LL akhir mendapati penurunan menjadi sebesar 89,729. Penurunan nilai -2LL ini memperlihatkan model regresi yang dihipotesiskan fit dengan data.

Analisis regresi logistik yang ketiga yaitu koefisien determinasi. Hasil dari koefisien determinasi bisa dilihat pada Tabel 6. 
Tabel 6.

Koefisien Determinasi

\begin{tabular}{lccc}
\hline Step & $\begin{array}{c}\mathbf{- 2 ~ L o g} \\
\text { likelihood }\end{array}$ & $\begin{array}{c}\text { Cox \& Snell R } \\
\text { Square }\end{array}$ & $\begin{array}{c}\text { Nagelkerke R } \\
\text { Square }\end{array}$ \\
\hline 1 & $89,729^{\text {a }}$ & 0,522 & 0,706 \\
\hline Sumber:data diolah, 2018 & &
\end{tabular}

Sesuai dengan Tabel 6, nilai nagelkerke r square sebesar 0,706 mempunyai arti sebanyak $70,6 \%$ variabilitas variabel terikat dijelaskan oleh variabel bebas, namunsisanya sebanyak 29,4\% dipengaruhi oleh variabel-variabel lain di luar penelitian.

Analisis regresi logistik yang kempat adalah uji multikolinieritas yang dipakai untuk menilai adanya korelasi antar variabel bebas. Hasil uji multikolinieritas bisa dilihat pada Tabel 7.

Tabel 7.

Matriks Korelasi

\begin{tabular}{|c|c|c|c|c|c|c|}
\hline & & Constant & $\begin{array}{c}\text { Ukuran } \\
\text { Perusahaa } \\
\mathbf{n} \\
\end{array}$ & Profitabilitas & $\begin{array}{l}\text { Financial } \\
\text { Leverage }\end{array}$ & $\begin{array}{c}\text { Winner } \\
\text { Loser } \\
\text { Stock } \\
\end{array}$ \\
\hline Step & Constant & 1,000 & $-0,879$ & $-0,496$ & $-0,524$ & $-0,148$ \\
\hline \multirow[t]{4}{*}{1} & $\begin{array}{l}\text { UkuranPeru } \\
\text { sahaan }\end{array}$ & $-0,879$ & 1,000 & 0,189 & 0,218 & 0,081 \\
\hline & $\begin{array}{l}\text { Profitabilita } \\
\mathrm{s}\end{array}$ & $-0,496$ & 0,189 & 1,000 & 0,236 & $-0,172$ \\
\hline & $\begin{array}{l}\text { FinancialLe } \\
\text { verage }\end{array}$ & $-0,524$ & 0,218 & 0,236 & 1,000 & 0,025 \\
\hline & $\begin{array}{l}\text { WinnerLos } \\
\text { erStock }\end{array}$ & $-0,148$ & 0,081 & $-0,172$ & 0,025 & 1,000 \\
\hline
\end{tabular}

Sumber: Data diolah, 2018

Sesuai dengan Tabel 7, dapat diketahui bahwa nilai matriks korelasi antar variabel lebih kecil dari 0,8 , sehingga tidak ada gejala multikolinieritas antara variabel tersebut.

Analisis regresi logistik kelima adalah matrik kalsifikasi. Hasil matrik klasifikasi dilihat pada Tabel 8. 
ISSN: 2302-8556

E-Jurnal Akuntansi Universitas Udayana

Vol.25.3.Desember (2018): 1913 - 1938

Tabel 8.

Matrik Klasifikasi

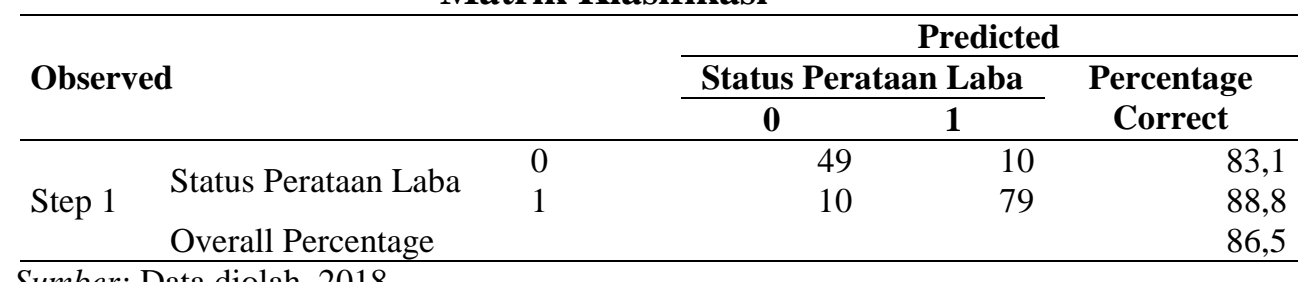

Sumber: Data diolah, 2018

Berdasarkan pada tabel 8, kekuatan prediksi dari model regresi untuk menduga kemungkinan perusahaan yang tidak melaksanakan perataan laba adalah sebanyak $83,1 \%$ ini bermakna dari 59 total observasi yang tidak melaksanakan perataan laba ada 49 total observasi diprediksi tidak melaksanakan perataan laba, sebaliknya 10 total observasi melaksanakan perataan laba. Kekuatan prediksi dari model regresi dalam memperkirakankesempatan perusahaan melaksanakan perataan laba adalah sebanyak $88,8 \%$ hal ini memperlihatkan, dari 89 total observasi yang melaksanakan perataan laba terdapat 76 total observasi melaksanakan perataan laba, sebaliknya 10 total observasi tidak melaksanakan perataan laba.

Analisis regresi logistik yang terakhir adalah model regresi yang terbentuk yang ditunjukkan pada Tabel 9. Berdasarkan pada Tabel 9 di atas dapat ditulis persamaan:

$\operatorname{Ln} \frac{P L}{1-P L}=-4,382+0,052 \mathrm{UP}+56,206 \mathrm{NPM}+0,274 \mathrm{DAR}-1,044 \mathrm{WLS}+\mathrm{e}$

Tabel 9.

Hasil Uji Regresi Logistik

\begin{tabular}{|c|c|c|c|c|c|c|}
\hline & & B & S.E. & Wald & df & Sig. \\
\hline \multirow{5}{*}{ Step $1^{\mathrm{a}}$} & UkuranPerusahaan & 0,052 & 0,057 & 0,807 & 1 & 0,369 \\
\hline & Profitabilitas & 56,206 & 9,396 & 35,780 & 1 & 0,000 \\
\hline & FinancialLeverage & 0,274 & 1,503 & 0,033 & 1 & 0,855 \\
\hline & WinnerLoserStock & $-1,044$ & 0,551 & 3,596 & 1 & 0,058 \\
\hline & Constant & $-4,382$ & 1,901 & 5,315 & 1 & 0,021 \\
\hline
\end{tabular}


Putu Intan Andriani, I G.A.M. Asri Dwija Putri dan Gede Agus Indra Tenaya K. Pengaruh...

Sumber: Data diolah, 2018

Variabel ukuran perusahaan mempunyai koefisien regresi sebesar 0,052 berarti setiap persen peningkatan ukuran perusahaan, dengan asumsi profitabilitas, financial leverage, dan winner/loser stock diduga tetap, sehingga kecenderungan perusahaan melaksanakan pemerataan laba semakin besar. Berdasarkan hasil pengujian terhadap variabel ukuran perusahaan bisa diketahui pada Tabel 4.9 menunjukkan hasil 0,369 yakni lebih besar dari signifikansi $5 \%$ atau 0,05 , yang berarti $\mathrm{H}_{0}$ diterima. Hal ini menunjukkan variabel ukuran perusahaan tidak berpengaruh pada perataan laba.

Variabel profitabilitas mempunyai koefisien regresi sebesar 56,206 bermakna setiap persen peningkatan profitabilitas, dengan ukuran perusahaan, financial leverage, dan winner/loser stock dianggap konstan, sehingga kecondongan perusahaan melaksanakan perataan laba menjadi lebih besar. Berdasarkan hasil pengujian terhadap variabel ukuran perusahaan dapat diketahui pada Tabel 4.9 menunjukkan hasil 0,000 yakni di bawah signifikansi 5\% atau 0.05, yang berarti $\mathrm{H}_{2}$ diterima. Hal ini menunjukkan bahwa variabel profitabilitas berpengaruh pada perataan laba.

Variabel financial leverage mempunyai koefisien regresi sebesar 0,274 bermakna setiap persen peningkatan financial leverage, dengan asumsi ukuran perusahaan, profitabilitas, dan winner/loser stock dianggap konstan, maka kecenderungan perusahaan melakukan perataan laba semakin besar. Berdasarkan hasil pengujian terhadap variabel ukuran perusahaan dapat diketahui pada Tabel 4.9 menunjukkan hasil 0,855 yakni di atas signifikansi $5 \%$ atau 0.05 , yang berarti $\mathrm{H}_{0}$ 
diterima dan $\mathrm{H}_{3}$ ditolak. Hal ini menunjukkan bahwa variabel financial leverage tidak berpengaruh pada perataan laba.

Variabel winner/loser stock mempunyai koefisien regresi-1,044 berarti setiap persen peningkatan financial leverage, dengan asumsi ukuran perusahaan, profitabilitas, dan winner/loser stock dianggap konstan, maka kecenderungan perusahaan melakukan perataan laba semakin kecil. Berdasarkan hasil pengujian terhadap variabel ukuran perusahaan dapat diketahui pada Tabel 4.9 menunjukkan hasil 0,058 yakni di atas signifikansi 5\% atau 0.05, yang berarti $\mathrm{H}_{0}$ diterima dan $\mathrm{H}_{4}$ ditolak. Hal ini memperlihatkan bahwa variabel winner/loser stock tidak mempunyai pengaruh pada perataan laba.

Sesuai dengan hasil analisis regresi logistik diketahui bahwa nilai signifikan sebanyak 0,369 yang nilainya lebih besar dari tingkat signifikansi $(\alpha=0,05)$ dan memiliki koefisien regresi sebesar 0,052. Hasil pengujian menunjukkan bahwa ukuran perusahaan tidak mempunyai pengaruh perataan laba. Semakin besar suatu perusahaan, maka perusahaan tersebut akan menjadi perhatian publik, sehingga manajemen akan cenderung lebih berhati-hati dalam melaporkan laba.

Penelitian ini searah dengan penelitian Widana dan Yasa (2013) bahwa ukuran perusahaan tidak mempunyai pengaruhpada perataan laba. Tidak berpengaruhnya ukuran perusahaan dapat disebabkan oleh penambahan total aktiva tidak menjamin perusahaan untuk melaksanakan perataan laba.

Sesuai dengan hasil analisis regresi logistik diketahui bahwa nilai signifikan sebesar 0,000 lebih kecil dari tingkat signifikansi $(\alpha=0,05)$ dan memiliki koefisien regresi sebesar 56,206. Hasil regresi logistik pada kecondongan perusahaan 
Putu Intan Andriani, I G.A.M. Asri Dwija Putri dan Gede Agus Indra Tenaya K. Pengaruh...

melakukan perataan laba, sehingga $\mathrm{H}_{2}$ diterima. Peningkatan profitabilitas akan memperbesar peluang manajer melakukan perataan laba.

Penelitian Fatmawati dan Atik Djajanti (2015) yang mengungkapkan bahwa perusahaan perusahaan yang mempunyai profitabilitas yang tinggi, condong melaksanakan perataan laba. Ini disebabkan oleh, peningkatan profitabilitas menyebabkan manajemen dengan mudah melaksanakan perataan laba dan memperlihatkan kinerja baik dari manajemen jika dinilai dari tingkat laba yang dihasilkan perusahaan.

Sesuai dengan hasil analisis regresi logistik diketahui bahwa nilai signifikan sebanyak 0,855 lebih besar dari tingkat signifikansi $(\alpha=0,05)$ dan memiliki koefisien regresi sebesar 0,274. Hasil pengujian memperlihatkan bahwa financial leverage tidak mempunyai pengaruh pada perataan laba. Hasil regresi logistik memperlihatkan bahwa variabel financial leverage tidak berpengaruh pada kecondongan perusahaan melakukan perataan laba, sehingga $\mathrm{H}_{3}$ ditolak. Ketika hutang suatu perusahaan meningkat, maka semakin tinggi rasio financial leverage.

Penelitian Widana dan Yasa (2013) mengungkapkan tidak berpengaruhnya financial leverage pada perataan laba dikarenakan perusahaan bisamembayar hutangsaat jatuh tempo dengan memakai modal yang dimiliki, sehingga perusahaan tidak mendapat masalah keuangan. Efek yang ditanggung pemilik modal juga semakin kecil, oleh karena itu manajemen tidak melaksanakan perataan laba.

Hasil analisis regresi logistik menunjukkan nilai signifikan sebanyak 0,058 lebih besar dari tingkat signifikansi $(\alpha=0,05)$ dengan koefisien regresi sebesar 1,044. Hasil pengujian memperlihatkan winner/loser stock tidak memengaruhi 
ISSN: 2302-8556

perataan laba, maka $\mathrm{H}_{4}$ ditolak. Ini bermakna manajemen tidak melihat harga saham selaku awal dalam melaksanakan perataan laba atau tidak.

Penelitian ini searah dengan penelitian Iskandar (2016) yang mengungkapkan winner/loser stock tidak mempunyai pengaruh pada perataan laba. Hasil peneltian ini berbeda dengan penelitian Dewi (2014) yang mengungkapkan winner/loser stock mempunyai pengaruh pada perataan laba.

Implikasi dari hasil penelitian ini terdiri dari implikasi teoritis dan praktis. Implikasi secara teoritis yaitu penelitian yang dilakukan diharapkan dapat memberikan kontribusi mengenai pengaruh ukuran perusahaan, profitabilitas, financial leverage dan winner/loser stock pada perataan labaperusahaan manufaktur. Hasil uji dalam penelitian ini ditemukan bahwa hanya variabel profitabilitas yang mempunyai pengaruh positif signifikan pada perataan laba.Sejalan dengan teori agensiyang mengungkapkan manajer bersikap oportunis dan tidak menyukai risiko, sehingga kondisi ini mendorong manajer untuk melaksanakan perataan laba.

Implikasi praktis penelitian ini adalah memberikan implikasi bagi penanam modal dan kreditor sebagai masukan dan pengetahuan tentang perataan laba serta faktor-faktor yang memengaruhinya. Investor dan kreditor dalam melakukan investasi di suatu perusahaan dapat melihat tingkat profitabilitas perusahaandalam mendeteksi perataan laba.

\section{SIMPULAN}

Simpulan yang didapat berdasarkan hasil penelitian adalah ukuran perusahaan tidak mempunyai pengaruh pada perataan laba. Hal ini menyatakan bahwa semakin besar 
Putu Intan Andriani, I G.A.M. Asri Dwija Putri dan Gede Agus Indra Tenaya K. Pengaruh...

perusahaan maka perusahaan akan lebih dipercaya dalam menyajikan laporan keuangannya, karena perusahaan besar dipandang lebih kritis oleh pemegang saham dan pihak luar. Profitabilitas berpengaruh terhadap perataan laba. Hal ini dikarenakan kecenderungan pihak investor menilai kinerja perusahaan dari laba bersih setelah pajak. Financial leveragetidak berpengaruh terhadap perataan laba. Ini dikarenakan perusahaan dapat melunasi kewajiban sesuai dengan waktu jatuh tempo sehingga manajemen tidak melaksanakan perataan laba. Winner/loser stock tidak mempunyai pengaruh pada perataan laba ini bermakna manajemen tidak melihat harga saham selaku awal dalammelaksanakan perataan laba atau tidak.

Saran yang dapat diberikan adalah penelitian selanjutnya adalah nilai Nagelkerke's $R$ Square sebesar 70,6\% menunjukkan bahwa masih terdapat banyak faktor lain yang berpengaruh terhadap kemungkinan perusahaan melakukan perataan laba. Penelitian selanjutnya dapat menambahkan variabel-variabel lain yang diduga dapat memengaruhi perataan laba.Penelitian selanjutnya sebaiknya dapat memperluas penggunaan sampel penelitian dengan tidak hanya menggunakan perusahaan manufaktur saja tetapi juga mempertimbangkan jenis sektor lain agar hasil penelitian dapat digunakan secara lebih luas oleh pembaca.

\section{REFERENSI:}

Alexandri, M. B. dan Anjani, W. K. 2014. Income Smoothing: Impact Factors, Evidence in Indonesia. International Journal of Small Business and Entrepreneurship Researh, 3(1), hal: 21-27.

Arfan, Muhammad dan Desry Wahyuni. 2010. Pengaruh Firm Size, Winner/Loser Stock, dan Debt to Equity Ratio terhadap Perataan Laba (Studi pada Perusahaan Manufaktur yang Terdaftar di Bursa Efek Indonesia. Jurnal Telaah \& Riset Akuntansi,3(1), hal: 52-65. 
Astuti, Sahening D. dan Endang Tri W. 2013. Analisis Pengaruh NPM, ROA, Ukuran Perusahaan, dan Financial Leverage terhadap Praktik Perataan Laba (Studi Kasus pada Perusahaan Manufaktur yang Terdaftar di BEI Tahun 2008-2011). Diponegoro Journal Of Management, hal: 1-14.

Beattie, Vivien.et al. 1994. Extraordinary Items and Income Smoothing: A Positive Accounting Approach. Journal of Business Finance \& Accounting, 21(6), pp: 791-811.

Budiasih, I G A N. 2009. Faktor-Faktor yang Mempengaruhi Praktik Perataan Laba. Jurnal Akuntansi dan Bisnis. Universitas Udayana, 8(2), hal 253-259.

https://m.detik.com/finance/bursa-dan-valas/238077/bapepam-denda-man tandireksi-indofarma-rp-500-juta. Diakses pada tanggal 20 November 2017.

Fatmawati dan Atik Djajanti. 2015. Pengaruh Ukuran Perusahaan, Profitabilitas dan Financial Leverage terhadap Praktik Perataan Laba pada Perusahaan Manufaktur yang Terdaftar di Bursa Efek Indonesia.Kelola, 2(3). ISSN: 2337-5965.

Handayani, Fitri dan Fuad. 2015. Faktor yang Berpengaruh terhadap Perataan Laba Perusahaan Otomotif yang Terdaftar di Bursa Efek Indonesia (BEI) Periode 2009-2012. Jurnal Akuntansi Diponegoro, 4(2), hal 1-12.

Iskandar, Andhika Fajar dan Ketut Alit Suardana. 2016. Pengaruh Ukuran Perusahaan, Return on Asset, dan Winner/Loser Stock terhadap Praktik Perataan Laba. E-Jurnal Akuntansi. Universitas Udayana.

Jensen, M. C. dan Meckling, W. H. (1976) "Theory of the Firm: Managerial Behavior, Agency Costs and Ownership Structure," Journal of Financial Economics, 3, hal. 305-360.

Juniarti dan Corolina. 2005. Analisis Faktor-Faktor yang Berpengaruh terhadap Perataan Laba (Income Smoothing) pada Perusahaan Go Public. Jurnal Akuntansi dan Keuangan, 7(2), hal: 148-161.

Kasmir. 2014. Analisa Laporan Keuangan. Jakarta: Rajawali Pers.

Kirschenheiter, M. \& N. Melumad. 2002. Can BigBath and Earnings Smoothing Co-exist as Equilibrium Financial Reporting Strategies? Journal of Accounting and Economics,40 (5), pp: 761-796.

Prasetya, Harris dan Rahardjo, Shiddiq Nur. 2013. Pengaruh Ukuran Perusahaan, Profitabilitas, Financial Leverage, Klasifikasi KAP, dan Likuiditas terhadap Praktik Perataan Laba. Jurnal Akuntansi Diponegoro, 2(4), hal: 1-7. 
Putu Intan Andriani, I G.A.M. Asri Dwija Putri dan Gede Agus Indra Tenaya K. Pengaruh...

Pratiwi, Ni Wayan Piwi Indah. 2017. Analisis Perataan Laba dan Faktor-faktor yang Mempengaruhinya. E-Jurnal Akuntansi,20(1), hal: 496-525.

Salno, Hanna Meilani dan Zaki Baridwan. 2000. “Analisis Perataan Penghasilan (Income Smoothing): Faktor-faktor yang Mempengaruhi dan Kaitannya dengan Kinerja Saham Perusahaan Publik di Indonesia". Jurnal Riset Akuntansi Indonesia, 3(1): hal:17-24.

Sugiyono. 2014. Metode Penelitian Bisnis. Bandung: CV. Alfabeta.

Supriastuti, S. dan Warnanti. A. 2015. Ukuran Perusahaan, Winner/Loser Stock, Debt to Equity Ratio, Dividend Payout Ratio Pengaruh terhadap Perataan Laba. Jurnal Paradigma, 13(01), hal: 45-62.

Suryani, Ayu Dewi. 2015. Pengaruh Ukuran Perusahaan, Debt to Equity Ratio, Profitabilitas dan Kepemilikan Institusional pada Perataan Laba. E-Jurnal Akuntansi,13(1), hal: 208-223.

Tucker, J W., \& Zarowin P.A. (2006). Doesincome smoothing improve earnings informativeness?. The Accounting Review, 81 (1), pp: 251-270.

Watt, Ross L., and Jerold L. Zimmerman. 1978. Toward A Positive Theory of The Determination of Accounting Standards. The Accounting Review, 53 (1), pp: 112-134.

Widana, I Nyoman Ari dan Gerianta Wirawan Yasa. 2013. Perataan Laba Serta Faktor-Faktor yang Mempengaruhinya di Bursa Efek Indonesia. E-Jurnal Akuntansi Universitas Udayana, 3(2) hal:297-317. 